\title{
ANNOUNCEMENTS
}

Pascal James Imperato Collection: Books on Mali at the American Embassy in Bamako

The American Embassy is establishing as part of its Cultural Center a collection of books on Mali. The primary emphasis will be on works by American authors, many of which are not available at this time in Mali. The collection will also contain a range of general works on Mali by authors of other nationalities.

Since US Government funds for this purpose are extremely limited, the Embassy is encouraging voluntary contributions of books and articles. Any members of the Association who have books or articles which they no longer need are encouraged to send them to Pascal James Imperato Collection, Attention American Cultural Center, BAMAKO/ DOS, Washington, DC 20521-2050.

The collection is named in honor of Pascal James Imperato, a noted epidemiologist and the author of numerous books and articles on Malian medicine, art and culture. It is hoped that the collection will serve as a demonstration of American scholarly interest in Mali, as well as an intellectual resource for both Malian and American residents in Bamako.

Africa-Related Theses and Dissertations at the University of Illinois at UrbanaChampaign, 1921-1988, compiled by Yvette Scheven, Africana Bibliographer at the University of Illinois Library, is available free of charge from the Center for African Studies, University of Illinois at Urbana-Champaign, Room 101, 1208 West California St., Urbana, IL 61801.

The report of the inaugural seminar of the Governance in Africa Program of the Carter Center "Perestroika without Glasnost in Africa," is now available and can be obtained by sending a check for $\$ 5.00$ endorsed to The Carter Center, One Copenhill, Atlanta, GA 30345. In addition to the major subjects discussed at the seminar, such as governance, the revitalization of associational life, liberalization, and the impact of international financial institutions, the Report includes an agenda for further research and action. By drawing on both the written papers and the keen debates at the seminar, the Report complements the Working Papers, Beyond Autocracy in Africa.

The Working Papers and Report can be obtained for a combined price of $\$ 13.50$. Individuals who have previously purchased Beyond Autocracy may obtain the report for $\$ 3.50$. In keeping with the policy of the program, single copies of these publications will be provided free of charge to colleagues in African institutions.

California Newsreel's Southern Africa Media Center has released its 1989-90 catalogue featuring the anti-apartheid drama, Mapantsula. Banned by the South African 
authorities, Mapantsula is a feature film in which the situation is seen solely from the perspective of black South Africans. Review cassettes and free catalogues are available upon request from The South African Media Center, California Newsreel, 149 9th Street, Room 420, San Francisco, CA 94103. Phone: (415) 621-6196. Fax: (415) 6216522.

\section{International African Institute Survey of Drought-Famine Activity in the African Sahel}

Drought and famine are closely linked though not synonymous. Drought- and famine-related problems are the product of a complex interaction between human-social and physical-environmental conditions.

The Sahelian drought of the late 1960s and early 1970s generated a tremendous but disparate volume of the research and policy documents; but these have taught us little about prediction, impact minimization and prevention. There is an urgent need to review the present stage of knowledge with a view to identifying gaps in research and information which must be plugged to ensure more effective coping mechanisms and management action.

The present survey, initiated by the International African Institute and funded generously by Band Aid, is being carried out by Dr. Reginald Cline-Cole, lecturer in Geography at Bayero University, Kano, Nigeria. It will adopt an interdisciplinary approach; cover both Anglophone and Francophone countries to facilitate communication between them; and identify little-known projects, often conducted by NGOs, so that their experience may be incorporated into future research programmes and policy initiatives.

The survey which falls into two parts - a bibliographic study and field visits will focus on the following broad themes:

- trends in the volume, distribution and nature of drought-famine aid;

- sub-regional cooperation in drought-famine research and development;

- early warning systems;

- emergency food security;

- long-term income redistribution policies, projects and programs for the reduction of household vulnerability to drought and famine;

- analyses of popular participation in and perceptions of drought-famine activities;

- nature, variety and impact of agricultural, pastoral, forestry and fishery activities in direct response to drought and famine.

This survey will result in a state-of-the-art report of 30-50,000 words. In reviewing ongoing projects it will provide a comprehensive guide to researchers and project managers, giving them access to data hitherto unavailable to them. It will assist donor agencies in targeting worthy recipients and will contain policy recommendations on how best to support indigenous research networks (for example, the Drylands Network of the IIED and the Refugee Study Network at Oxford).

The International African Institute plans to hold a seminar in one of the countries covered by the study as soon as possible after the completion of the report in order to discuss its findings. Participants, numbering between 20 and 30, will include active re- 
searchers or project managers identified in the course of the survey, and representatives of donor agencies and policy making bodies. In a week of intensive discussion the seminar will strengthen links between those working in the field and the donor or policy making agencies; foster links between anglophone and francophone organizations and between the different social science disciplines involved. It will indicate the relevance of recent research to policy making and will provide guides for future research; it will contribute to the development of appropriate evaluation systems to monitor the progress of development projects designed to alleviate the effects of famine and drought.

\section{Amnesty International's International Campaign to Abolish the Death Penalty}

On April 25th Amnesty International began its international campaign to Abolish the Death Penalty. This campaign will continue through the rest of the year and will target death penalty practices in the United States, China, Iran, Iraq and the Soviet Union, as well as in two African countries, Nigeria and South Africa.

Nigeria: The death penalty in Nigeria has been a major concern to Amnesty International for many years. AI has taken up the issue with govemment officials, target sectors and others through direct approaches from AI's Secretary General and various other AI actions. These has been a mixed response from government officials and individuals in Nigeria, some of it positive. The military government that came to power in August 1985 has restricted the scope of the death penalty by repealing certain death penalty legislation and the number of executions is believed to have declined since then. The high incidence of armed robbery, however, is a very real issue of concern among Nigerians and has been one of the principal reasons why the government has retained the death penalty for this offense. During the campaign, certain aspects of the death penalty in Nigeria will be singled out for special attention in the hope of positive results which may lead to the abolition of the death penalty in the long-term. These special issues of concern are: high number of death sentences and executions; death sentences imposed with no right of appeal; children under 18 at the time of the offense may be executed; and public executions.

South Africa: Executions have exceeded one hundred a year in South Africa in recent years, and the percentage of death sentences commuted by the authorities has declined. In 1988 there were 117 reported executions, excluding those in the nominally independent "homelands;" and in 1987 there was a total of at least 172 executions in the whole of South Africa, the highest figure since independence in 1910. Death sentences are imposed disproportionately on the black population by an almost entirely white judiciary (of the people executed in 1987, 163 were black and 9 white). South African lawyers have criticized the inadequacies of the legal aid system, the lack of automatic right of appeal and other procedural issues which prejudice the position of poor, mostly black defendants. The death penalty is increasingly imposed at political trials or trials for politically-related killings. Defendants in these cases are often held incommunicado for long periods before being brought to trail; some have been physically tortured, and statements they or others have made during prolonged periods of incommunicado detention often form the basis of the prosecution's evidence against them. 